\title{
Characterization of osteoarthritic human knees indicates potential sex differences
}

Qingfen Pan', Mary I. O'Connor ${ }^{2}$, Richard D. Coutts ${ }^{3}$, Sharon L. Hyzy ${ }^{4}$, Rene Olivares-Navarrete ${ }^{4}$, Zvi Schwartz ${ }^{4,5}$ and Barbara D. Boyan ${ }^{4,6,7^{*}}$

\begin{abstract}
Background: The prevalence of osteoarthritis is higher in women than in men in every age group, and overall prevalence increases with advancing age. Sex-specific differences in the properties of osteoarthritic joint tissues may permit the development of sex-specific therapies. Sex hormones regulate cartilage and bone development and homeostasis in a sex-dependent manner. Recent in vitro studies show that the vitamin $\mathrm{D}_{3}$ metabolite 1a,25-dihydroxyvitamin D3 $\left[1 a, 25(\mathrm{OH})_{2} \mathrm{D}_{3}\right]$ also has sex-specific effects on musculoskeletal cells, suggesting that vitamin $D_{3}$ metabolites may play a role in osteoarthritis-related sex-specific differences. The purpose of this study was to determine if sex-specific differences exist in synovial fluid and knee tissues isolated from male and female patients with severe knee osteoarthritis. We determined the presence of vitamin $\mathrm{D}_{3}$ metabolites, inflammatory cytokines, growth factors, and matrix metalloproteinases (MMPs) in synovial fluid and assessed responses of articular chondrocytes and subchondral osteoblasts to $17 \beta$-estradiol, dihydrotestosterone, and $1 \mathrm{a}_{1} 25(\mathrm{OH})_{2} \mathrm{D}_{3}$.

Methods: Samples from knee joints of 10 Caucasian male and 10 Caucasian female patients with advanced osteoarthritis aged 65 to 75 years were obtained from total knee arthroplasty. Vitamin D metabolites, cytokines, MMPs, and growth factors in the synovial fluid were measured. Primary cultures of chondrocytes were isolated from fibrillated articular cartilage adjacent to osteoarthritis lesions and minimally affected cartilage distal to the lesion. Osteoblasts were isolated from the subchondral bone. Expression of receptors for $17 \beta$-estradiol and $1 \mathrm{a}, 25(\mathrm{OH})_{2} \mathrm{D}_{3}$ was assessed by real-time PCR. Chondrocytes and osteoblasts were treated with $10^{-8} \mathrm{M} 17 \beta$-estradiol, dihydrotestosterone, or $1 \mathrm{a}, 25(\mathrm{OH})_{2} \mathrm{D}_{3}$ and effects on gene expression and protein synthesis determined.
\end{abstract}

Results: Histology of the articular cartilage confirmed advanced osteoarthritis. Sex differences were found in synovial fluid levels of vitamin D metabolites, cytokines, and metalloproteinases as well as in the cellular expression of receptors for $17 \beta$-estradiol and $1 \mathrm{a}, 25(\mathrm{OH})_{2} \mathrm{D}_{3}$. Male cells were more responsive to $1 \mathrm{a}, 25(\mathrm{OH})_{2} \mathrm{D}_{3}$ and dihydrotestosterone, whereas $17 \beta$-estradiol-affected female cells.

Conclusions: These results demonstrate that there are underlying sex differences in knee tissues affected by osteoarthritis. Our findings do not address osteoarthritis etiology but have implications for different prevention methods and treatments for men and women. Further research is needed to better understand these sex-based differences.

Keywords: Osteoarthritis, Chondrocytes, Osteoblasts, Estrogen, Testosterone, Dihydrotestosterone, $1 \mathrm{a}, 25(\mathrm{OH})_{2} \mathrm{D}_{3}$, $24 \mathrm{R}, 25(\mathrm{OH})_{2} \mathrm{D}_{3}$, Vitamin D

\footnotetext{
* Correspondence: bboyan@vcu.edu

${ }^{4}$ Department of Biomedical Engineering, Virginia Commonwealth University,

Richmond, VA, USA

${ }^{6}$ Wallace H. Coulter Department of Biomedical Engineering, Georgia Institute

of Technology, Atlanta, GA, USA

Full list of author information is available at the end of the article
} 


\section{Background}

Osteoarthritis (OA) is a leading cause of pain and disability in adults. Nearly one in two people may develop symptomatic knee $\mathrm{OA}$ by age 85 [1]. OA affects the whole joint, including the articular cartilage, subchondral bone, muscle, tendons, meniscus, and synovium, and impacts daily life and function. Symptoms may include joint pain, tenderness, stiffness, and locking [2]. A variety of causes, including hereditary, developmental, metabolic, and mechanical deficits, may initiate processes leading to cartilage loss. Risk factors for developing OA include patient sex, race/ethnicity, joint instability, obesity, joint trauma, and age. Epidemiologic studies show sex-specific differences in the prevalence and severity of OA $[3,4]$. On average, the rate of arthritis is $58 \%$ higher in women than in men [5]. Women report more pain due to OA than men report and are more likely to have reductions in function and quality of life [6]. Biomechanical differences between men and women may contribute to differences in OA prevalence, although data supporting this are not clear [7]; thus, other sex differences may be involved.

Sex hormones are important regulators of cartilage biology. Ovariectomized Cynomolgus monkeys exhibit histopathologic features typical of OA, suggesting that estrogen has a protective effect [8]. Studies using a mouse model of OA support this; ovariectomized female mice had more OA than intact mice, but orchidectomized male mice had less severe OA than intact males [9]. A number of studies have shown sexual dimorphism in the response of chondrocytes and osteoblasts to $17 \beta$ estradiol (E2) and dihydrotestosterone (DHT) at the cellular level [10-12]; however, the effects of sex hormones on the incidence and progression of OA of the knee, as well as on the regenerative potential of affected cartilage, are poorly understood.

Studies indicate that bone and cartilage cells exhibit sex-specific responses to the vitamin $\mathrm{D}$ metabolites $1 \alpha, 25$-dihydroxyvitamin D3 $\left[1,25(\mathrm{OH})_{2} \mathrm{D}_{3}\right]$ and $24 \mathrm{R}, 25-$ dihydroxyvitamin D3 $\left[24,25(\mathrm{OH})_{2} \mathrm{D}_{3}\right] \quad[13-15]$. In addition to its role in maintaining calcium homeostasis and bone metabolism [16-18], recent evidence suggests that $1,25(\mathrm{OH})_{2} \mathrm{D}_{3}$ plays important roles in cartilage remodeling and participates in the inflammatory response $[19,20]$. Epidemiologic studies have correlated low serum levels of 25-hydroxyvitamin $\mathrm{D}_{3}\left[25(\mathrm{OH}) \mathrm{D}_{3}\right]$, the precursor of $1,25(\mathrm{OH})_{2} \mathrm{D}_{3}$ and $24,25(\mathrm{OH})_{2} \mathrm{D}_{3}$, with $\mathrm{OA}$ progression [21]. Moreover, vitamin D supplementation had a protective effect against $\mathrm{OA}$ in rats by reducing messenger RNAs (mRNAs) for matrix metalloproteinase (MMP)-3, interleukin-1 $\beta$ (IL1 $\beta)$, and tumor necrosis factor alpha (TNF $\alpha$ ), factors associated with cartilage degradation and inflammation [22]. Interestingly, $1 \alpha, 25(\mathrm{OH})_{2} \mathrm{D}_{3}$ induced production of E2 in female rat chondrocytes but not in male chondrocytes, further demonstrating that there is sexual dimorphism at the cellular level [23].

As a first step in understanding how sex differences might have an impact on OA, we investigated whether differences were present in patients with OA sufficiently severe to warrant total joint replacement. We reasoned that the disease was comparable in patients of both sexes, and while the etiology of the disease in any one patient was unknown, all patients would receive the same treatment. Thus, identified differences would be more likely to be intrinsic to the sex of the patient, rather than random non-specific observations. We examined serum and synovial fluid obtained at the time of surgery as well as the morphology of the articular cartilage. Also, we isolated chondrocytes and osteoblasts and examined their responses to $1 \alpha, 25(\mathrm{OH})_{2} \mathrm{D}_{3}, \mathrm{E} 2$, and DHT.

\section{Methods}

\section{Patient population}

Surgeries and preclinical assessments were performed at Mayo Clinic, Jacksonville, FL, USA. Bench studies were conducted at Georgia Institute of Technology, Atlanta, GA, USA, and Virginia Commonwealth University, Richmond, VA, USA. Analyses for the studies were performed at all locations listed under affiliations. Each author certifies that his or her institution approved the human protocol for this investigation (Mayo Clinic - 11001468; Georgia Tech - H11239; VCU - HM15270), and that all investigations were conducted in conformity with ethical principles of research, and that informed consent for participation in the study was obtained.

Twenty white, non-Hispanic patients (10 men/10 women) between the ages of 65 and 75 years, who were undergoing total knee arthroplasty (TKA) due to severe OA of the knee, were included in our study. Patients with inflammatory arthritis, osteonecrosis, prior upper tibial osteotomy, premenopausal women, patients aged less than 65 years or aged greater than 75 years; who were insulin-dependent or diabetic, with a BMI greater than $30 \mathrm{~kg} / \mathrm{m}^{2}$, or history of knee infection were excluded from our study (Table 1). The study size of 20 was powered based on serum $25(\mathrm{OH}) \mathrm{D}_{3}$ levels, given an alpha of 0.05 , a standard deviation of 17 , an effect size of 22.5 , and power of 0.8 .

Information collected at the Mayo Clinic before surgery included patient demographics (age, sex, body mass index [BMI]) and medication and supplement use (vitamin D supplements, bisphosphonates, and estrogen). In addition, we used several rating scales to provide baseline information on the two patient cohorts in the event that sex differences were observed. These included the Short Form-12 (SF-12) Health Survey, the Western Ontario \& McMaster Universities Arthritis Index (WOMAC), and 
Table 1 Patient demographics and clinical history

\begin{tabular}{|c|c|c|c|}
\hline Variable & Female & Male & $p$ value $e^{a}$ \\
\hline Median age (IQR) - years & $70(68,71)$ & $69(66,72)$ & 0.42 \\
\hline Median body mass index (IQR) $-\mathrm{kg} / \mathrm{m}^{2}$ & $26.2(25.6,28.1)$ & $27.0(24.3,28.6)$ & 0.34 \\
\hline Vitamin D use - no. $(\%)^{\mathrm{b}}$ & & & 0.14 \\
\hline Currently & $6(60 \%)$ & $3(30 \%)$ & \\
\hline Previously & $3(30 \%)$ & $2(20 \%)$ & \\
\hline Never & $1(10 \%)$ & $5(50 \%)$ & \\
\hline Median 25-hydroxy D3 (IQR) - ng/ml & $42.1(33.7,47.2)$ & $38.4(31.0,52.6)$ & 0.79 \\
\hline Bisphosphonates use - no. $(\%)^{b}$ & & & 0.47 \\
\hline Previously & $2(20 \%)$ & $0(0 \%)$ & \\
\hline Never & $8(80 \%)$ & $10(100 \%)$ & \\
\hline Estrogen use - no. $(\%)^{b}$ & & & $<0.001$ \\
\hline Currently & $4(40 \%)$ & $0(0 \%)$ & \\
\hline Previously & $4(40 \%)$ & $0(0 \%)$ & \\
\hline Never & $2(20 \%)$ & $10(100 \%)$ & \\
\hline Previously injured a knee so badly it was difficult to walk for at least a week - no. (\%) & $0(0 \%)$ & $3(30 \%)$ & 0.21 \\
\hline Prior knee surgery - no. (\%) & $6(60 \%)$ & $6(60 \%)$ & 1.00 \\
\hline Prior intra-articular injections of steroids - no. (\%) & $7(70 \%)$ & $5(50 \%)$ & 0.65 \\
\hline Median no. of steroid injections (IQR) & $1(0,1)^{c}$ & $1(0,3)$ & 0.58 \\
\hline Prior intra-articular injection of hyaluronic acid - no. (\%) & $3(30 \%)$ & $5(50 \%)$ & 0.65 \\
\hline Median no. of hyaluronic injections (IQR) & $0(0,1)$ & $2(0,3)$ & 0.30 \\
\hline Knee to be replaced - no. (\%) & & & 1.00 \\
\hline Right & $6(60 \%)$ & 6 (60 \%) & \\
\hline Left & $4(40 \%)$ & $4(40 \%)$ & \\
\hline
\end{tabular}

IQR interquartile range

${ }^{a} p$ values result from a Wilcoxon rank sum test for numerical variables and Fisher's exact test for categorical variables

${ }^{\mathrm{b}} p$ values are based on categorization as currently or previously used vs. never used

Information was not available for 1 patient

the Physical Activity Scale for the Elderly (PASE) functional scale tests. Serum $25(\mathrm{OH}) \mathrm{D}_{3}$ levels and standard radiographs were obtained for each patient. Within 2 weeks of surgery, patients completed the Osteoarthritis Research Society International-Outcome Measures in Rheumatology (OARSI-OMERACT) pain scale [24], the knee pain map [25], and pressure-pain thresholds at the knee using JTECH Tracker wireless software (V.5; JTECH Medical, Midvale, UT, USA) [26, 27].

Although not statistically significant, there was some evidence to suggest that previous or current vitamin D use was more common in women patients than in men patients ( 90 vs. $50 \% ; p=0.14$ ). As expected, only the female cohort reported previous or current estrogen use ( 80 vs. $0 \% ; p<0.001$ ). There was no evidence of a difference in age, BMI, bisphosphonate use, prior knee surgery, prior intraarticular steroid injections, or prior intraarticular hyaluronic acid injections between men and women patients $(p \geq 0.21)$.

Per preoperative radiographic and knee pain assessments, the pain-pressure threshold $1 \mathrm{~cm}$ above the medial joint line was lower in women than men (median, 3.0 vs. $5.1 \mathrm{~kg} ; p=0.007$ ) (Table 2). There was no evidence of a difference in patient serum levels of $25(\mathrm{OH}) \mathrm{D}_{3}$, radiographic assessment, knee pain, or areas of knee pain $(p \geq 0.37)$. There was no evidence of a difference between male and female patients in the pain and functional assessments before surgery, including the WOMAC, OARSI-OMERACT, and SF-12 $(p \geq 0.36)$ (Table 3).

All patients exhibited similar morphologic and histological features. All patients had radiographic evidence of joint narrowing and bone-bone contact (Fig. 1a).

\section{Sample collection}

Fresh human tissue was obtained from consenting patients undergoing elective TKA at Mayo Clinic, Jacksonville, FL, USA. Synovial fluid was aspirated from the knee joint prior to skin incision, snap frozen, and stored at $-80{ }^{\circ} \mathrm{C}$. Bone, with overlaying cartilage specimens from the distal and posterior medial and lateral femoral condyles, and the proximal tibial bone cut were 
Table 2 Preoperative knee pain and radiographic assessment

\begin{tabular}{|c|c|c|c|}
\hline Variable & Female & Male & $p$ value $^{a}$ \\
\hline \multicolumn{4}{|l|}{ Radiographic assessment } \\
\hline Kellgren-Lawrence Grading Scale - no. (\%) & & & 0.37 \\
\hline Grade 3 & $1(10 \%)$ & $0(0 \%)$ & \\
\hline Grade 4 & $9(90 \%)$ & $10(100 \%)$ & \\
\hline \multicolumn{4}{|l|}{ Median pain-pressure threshold (IQR) - kg } \\
\hline Medial joint line & $4.5(3.7,5.1)$ & $5.3(4.1,6.9)$ & 0.16 \\
\hline $1 \mathrm{~cm}$ above the medial joint line & $3.0(2.7,3.8)$ & $5.1(4.5,6.2)$ & 0.007 \\
\hline $1 \mathrm{~cm}$ below the medial joint line & $4.0(3.5,4.1)$ & $5.6(4.0,6.8)$ & 0.10 \\
\hline \multicolumn{4}{|l|}{ Area(s) of knee pain - no. $(\%)^{b}$} \\
\hline \multicolumn{4}{|l|}{ Localized } \\
\hline Superior lateral & $0(0 \%)$ & $1(10 \%)$ & 1.00 \\
\hline Patella & $0(0 \%)$ & $1(10 \%)$ & 1.00 \\
\hline Medial joint line & $3(30 \%)$ & $2(20 \%)$ & 1.00 \\
\hline Inferior lateral & $1(10 \%)$ & $0(0 \%)$ & 1.00 \\
\hline Inferior medial & $1(10 \%)$ & $0(0 \%)$ & 1.00 \\
\hline \multicolumn{4}{|l|}{ Regional } \\
\hline Medial & $1(10 \%)$ & $1(10 \%)$ & 1.00 \\
\hline Patella & $1(10 \%)$ & 2 (20 \%) & 1.00 \\
\hline Diffuse pain & $4(40 \%)$ & $3(30 \%)$ & 1.00 \\
\hline
\end{tabular}

${ }^{a} p$ values result from a Wilcoxon rank sum test for numerical variables and Fisher's exact test for categorical variables

${ }^{\mathrm{b}}$ More than one location per patient was possible. Pain was not reported at any of the following locations: superior medial, lateral joint line, back of knee, lateral (regional), and back of knee (regional)

also obtained. Bone/cartilage specimens were shipped, on ice, to the Institute for Bioengineering and Bioscience at the Georgia Institute of Technology (Atlanta, GA, USA) or the School of Engineering, Institute for Engineering and Medicine at Virginia Commonwealth University (VCU; Richmond, VA, USA). Upon receipt, knee tissues were dissected, separating articular cartilage, subchondral bone, synovial membrane, and meniscus. Tissues were coded using de-identified patient numbers provided by Mayo Clinic. Articulating surfaces of the tibia and femur were photographed. Chondrocytes and osteoblasts were isolated at the time of receipt; meniscus, synovium, bone, and cartilage were processed for histology. Synovial fluid was thawed and aliquoted, then stored at $-80{ }^{\circ} \mathrm{C}$

Table 3 Pain and functional assessment prior to surgery

\begin{tabular}{|c|c|c|c|}
\hline Variable & Female & Male & $p$ value $^{a}$ \\
\hline \multicolumn{4}{|l|}{ WOMAC } \\
\hline Median total raw score (IQR) & $39(32,47)$ & $45(27,55)$ & 0.76 \\
\hline Median pain score (IQR) & $8.5(7,10)$ & $9.0(5,12)$ & 0.73 \\
\hline Median stiffness score (IQR) & $4.0(2,5)$ & $4.0(3,6)$ & 0.64 \\
\hline Median difficulty performing daily activities score (IQR) & $28(21,33)$ & $32(18,38)$ & 0.70 \\
\hline \multicolumn{4}{|l|}{ OARSI-OMERACT pain scale } \\
\hline Median total pain score (IQR) & $49(30,59)$ & $42(39,61)$ & 0.88 \\
\hline Median constant pain subscore (IQR) & $45(20,55)$ & $38(25,45)$ & 0.36 \\
\hline Median intermittent pain subscore (IQR) & $48(42,63)$ & $50(42,67)$ & 0.70 \\
\hline \multicolumn{4}{|l|}{ SF-12 } \\
\hline Median physical scale (IQR) & $33(29,42)^{b}$ & $38(30,39)$ & 0.55 \\
\hline Median mental scale (IQR) & $61(54,63)^{b}$ & $57(54,66)$ & 0.90 \\
\hline
\end{tabular}

${ }^{a} p$ values result from a Wilcoxon rank sum test

b Information was not available for 1 patient 

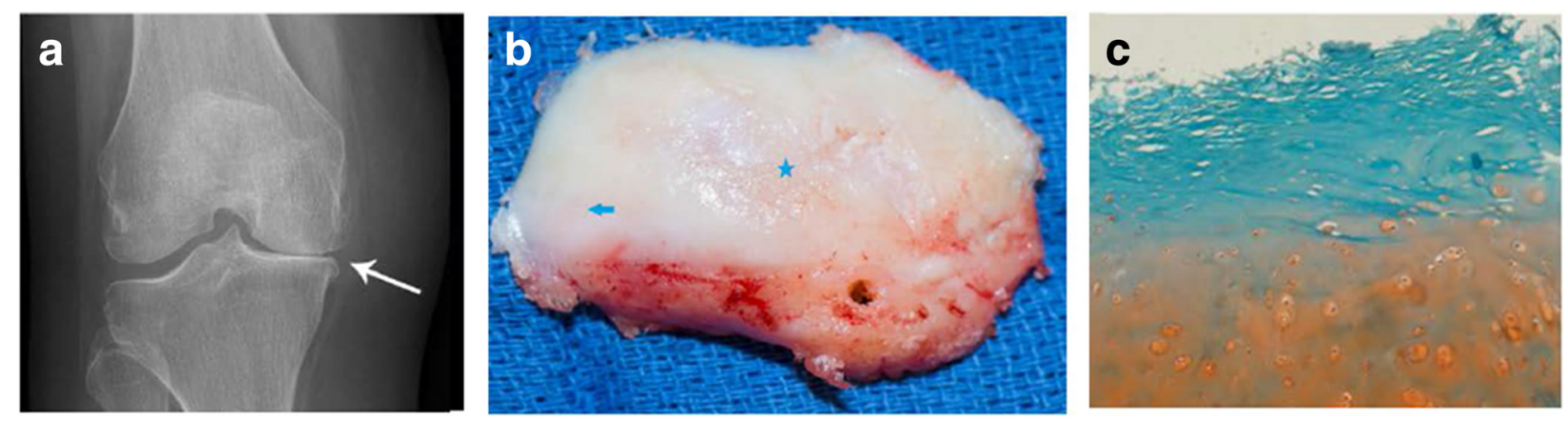

Fig. 1 Gross changes in osteoarthritic joints. a Radiograph showing joint narrowing and bone-to-bone contact. b Articular cartilage showing areas of minimal fibrillation (arrow) and areas of maximum erosion (star). c Safranin-O-stained fibrillated cartilage showing loss of proteoglycan

until used. All assays performed at VCU were blinded to donor sex.

\section{Histology}

Following fixation in $10 \%$ formalin, cartilage was decalcified (Decal Chemical Corporation, Tallman, NY, USA) for $16 \mathrm{~h}$ on a rotating platform before undergoing dehydration in a series of 95 and $100 \%$ ethanol and xylene washes. Samples were embedded in paraffin; $7-\mu \mathrm{m}$ sections were stained with safranin-O to assess glycosaminoglycan content.

\section{Synovial fluid}

Synovial fluid levels of $1,25(\mathrm{OH})_{2} \mathrm{D}_{3}$ were measured according to manufacturer's instructions using a human $1,25(\mathrm{OH})_{2} \mathrm{D}_{3}$ ELISA kit $\left(\mathrm{DHVD}_{3}\right.$, Novatein Biosciences, Cambridge, MA, USA). Levels of $25(\mathrm{OH}) \mathrm{D}_{3}$ were measured according to manufacturer's instructions using a human 25-hydroxyvitamin $\mathrm{D}_{3}$ ELISA kit $\left(25 \mathrm{HVD}_{3}\right.$, Novatein Biosciences). In addition, we used an ELISA kit from Immunodiagnostic Systems (Gaithersburg, MD, USA) that measured $25(\mathrm{OH}) \mathrm{D}_{3}, 25(\mathrm{OH}) \mathrm{D}_{2}$, and $24,25(\mathrm{OH})_{2} \mathrm{D}_{3}$. We then approximated the amount of $24,25(\mathrm{OH})_{2} \mathrm{D}_{3}$ plus $25(\mathrm{OH}) \mathrm{D}_{2}$ by subtracting the values for $25(\mathrm{OH}) \mathrm{D}_{3}$ that had been obtained using the Novatein Biosciences assay. Because other vitamin D metabolites might have also been present, including $1,24,25(\mathrm{OH})_{3} \mathrm{D}_{3}$, mass spectrometry (Thermo Vantage Triple Quadrupole Mass Spectrometer; Biotrial, Quebec, Canada) was used to measure $24,25(\mathrm{OH})_{2} \mathrm{D}_{3}$ specifically. Data were calculated per milliliter of synovial fluid.

Inflammatory cytokines and MMPs present in the synovial fluid were measured using a Luminex screening assay (R\&D Systems, Minneapolis, MN, USA). This assay uses superparamagnetic beads coated with analytespecific antibodies. Transforming growth factor beta-1 (TGF $\beta 1$ ), TGF $\beta 2$, and TGF $\beta 3$ levels were measured using a magnetic bead-based multiplex assay (Bio-Rad, Hercules, CA, USA). Sulfated glycosaminoglycan levels were measured using the dimethyl methylene blue assay (Sigma-Aldrich, St. Louis, MO, USA) [28]. In all cases, data were determined per milliliter of synovial fluid.

\section{Chondrocyte cultures}

Articular cartilage was harvested by sharp dissection from areas of minimal fibrillation and areas of maximum erosion (Fig. 1b). Cartilage pieces were minced and incubated in Dulbecco's modified Eagle's medium (DMEM; Thermo Fisher, Waltham, MA, USA) containing $0.25 \%$ trypsin (Life Technologies, Carlsbad, CA, USA) for $30 \mathrm{~min}$ at $37^{\circ} \mathrm{C}$. After discarding the trypsin digest, chondrocytes were isolated from cleaned cartilage fragments by incubating them for $16 \mathrm{~h}$ in $0.03 \%$ type-II collagenase (Worthington Biosciences, Lakewood, NJ, USA) in DMEM containing $100 \mathrm{U} / \mathrm{mL}$ penicillin and $100 \mu \mathrm{g} / \mathrm{mL}$ streptomycin. Cells were separated from remaining cartilage pieces by straining the mixture through a $40-\mu \mathrm{m}$ filter. Cells were cultured in DMEM supplemented with $10 \%$ fetal bovine serum (Life Technologies) and $100 \mathrm{U} / \mathrm{mL}$ penicillin and $100 \mu \mathrm{g} / \mathrm{mL}$ streptomycin. A preliminary study demonstrated that first-passage cells retained their chondrocyte phenotype, whereas cells at later passages did not. Therefore, passage 1 cells were used for all experiments and cells were seeded at $15,000 / \mathrm{cm}^{2}$ for all experiments. We have successfully identified differences at the cellular level with as few as three donors per group [29], but we opted to culture the cells from all 20 patients. Unfortunately, there was not sufficient tissue available in some cases; in other instances, cell growth was inadequate. The final sample size for the cell culture studies was 6 males and 6 females.

In order to determine if chondrocytes were competent to respond to hormone treatment, mRNA levels for receptors for $1,25(\mathrm{OH})_{2} \mathrm{D}_{3}$ (vitamin D receptor [VDR] and protein disulfide isomerase A3 [PDIA3]) or E2 (ER 666 [ESR1] and ER $\alpha 36)$ were measured in chondrocytes from both fibrillated and minimally affected OA tissues via 
real-time qPCR [30]. The cells were further characterized with respect to basal expression of inflammatory cytokines (IL1A, IL1B, IL6, IL8, and IL10) [31]. Related work has shown that differentiation of chondrocytes in response to $1,25(\mathrm{OH})_{2} \mathrm{D}_{3}$ involves signaling via winglessInt pathway molecules (WNT3A, WNT5A, CTNNB, DKK1, and DKK2) [32]; therefore, we also measured RNA expression for these proteins. Primers for each of the mRNAs are shown in Additional file 1: Table S1.

RNA was harvested using a TRIzol (Invitrogen, Carlsbad, CA, USA) extraction method following manufacturer's protocol. RNA was quantified using a NanoDrop spectrophotometer (Thermo Scientific, Waltham, MA, USA) and specific mRNAs (250 ng) were amplified using reverse transcription (High-Capacity cDNA Reverse Transcription Kit; Life Technologies). Starting quantities of mRNA were determined using SybrGreen chemistry (Power SYBR; Green PCR Master Mix, Life Technologies) in a StepOne Plus imaging system (Life Technologies). All gene expression was normalized to glyceraldehyde-3-phosphate dehydrogenase (GAPDH).

In order to examine if there were sex differences in response to hormonal treatment, confluent first passage chondrocytes were treated with $10^{-8} \mathrm{M} 1 \alpha, 25(\mathrm{OH})_{2} \mathrm{D}_{3}$ (Enzo Life Sciences, Plymouth, PA, USA) or $10^{-8} \mathrm{M}$ E2 (Sigma-Aldrich, St. Louis, MO, USA). In addition, cells were treated with $10^{-7} \mathrm{M} 24 \mathrm{R}, 25(\mathrm{OH})_{2} \mathrm{D}_{3}$ (Enzo Life Sciences) or $10^{-8}$ M $5 \alpha$-DHT (Sigma-Aldrich). mRNAs for aggrecan (ACAN), type-II collagen (COL2A1), and cartilage oligomeric matrix protein (COMP) were measured at $12 \mathrm{~h}$ using real-time qPCR. Primers used are listed in Additional file 1: Table S1.

To measure alkaline phosphatase specific activity, confluent first-passage cells were treated for $24 \mathrm{~h}$ with either vehicle $\left(0.01 \%\right.$ ethanol), or $10^{-8} \mathrm{M} 1 \alpha, 25(\mathrm{OH})_{2} \mathrm{D}_{3}$ or E2. Cells were harvested by trypsin digestion and were lysed in Triton X-100 (Sigma-Aldrich). Enzyme activity was measured by assaying the release of $p$-nitrophenol from $p$-nitrophenylphosphate at a $\mathrm{pH}$ of 10.2 in the cell lysates and was normalized to total protein content of the cell lysates (BCA Protein Assay; Thermo Fisher Scientific, Waltham, MA, USA) [33].

\section{Osteoblast cultures}

Subchondral bone samples obtained from regions under minimally fibrillated cartilage and regions of maximal cartilage erosion were minced into small chips, incubated with $0.25 \%$ trypsin for $30 \mathrm{~min}$ at $37^{\circ} \mathrm{C}$, and then washed with DMEM with $1 \%$ penicillin-streptomycin three times. After washing, bone chips were cultured for 2 weeks in Petri dishes containing DMEM with $1 \%$ penicillin-streptomycin and $10 \%$ fetal bovine serum to enable osteoprogenitor cells to migrate out onto the dish surface. Media were changed once a week until cells reached confluence. Cells were then subcultured by seeding at 10,000 cells $/ \mathrm{cm}^{2}$ for all experiments.

The presence of receptors for $1 \alpha, 25(\mathrm{OH})_{2} \mathrm{D}_{3}$ and E2 was assessed as described for the chondrocyte cultures above. Response to the hormones was examined using confluent first-passage osteoblasts treated with either vehicle $\left(0.01 \%\right.$ ethanol) or $10^{-8} \mathrm{M} 1 \alpha, 25(\mathrm{OH})_{2} \mathrm{D}_{3}$, E2 or DHT for $24 \mathrm{~h}$. The conditioned media were collected, and levels of secreted osteocalcin and osteoprotegerin were determined. Osteocalcin was measured using a commercially available radioimmunoassay following manufacturer's instructions (Biomedical Technologies, Stoughton, MA, USA) [34]. Osteoprotegerin was measured by ELISA (R\&D Systems, Minneapolis, MN, USA) [35]. After decanting the conditioned media, cells were harvested by trypsin digestion and alkaline phosphatase-specific activity was determined in cell lysates. DNA was measured using a fluorometric assay from Promega (Madison, WI, USA). Levels of secreted factors in the conditioned media were normalized to total DNA.

\section{Statistical analysis}

Clinical data were summarized for each sex by the sample median and interquartile (IQR) range for numerical variables whereas categorical variables were summarized by frequency and percentage. Comparisons between men and women were evaluated using a Wilcoxon rank sum test for numerical variables, Cochran-Armitage test for trend for ordered variables, and Fisher exact test for categoric variables. Statistical significance was considered at $p<0.05$ without adjustment for multiple testing, owing to the exploratory and hypothesis-generating nature of the study. The considerable number of tests performed increased the chance of a type-I error, and interpretation of study results should consider this. Additionally, the small sample size increased the chance of a type-II error (i.e., false-negative association). Statistical analyses were performed using SAS statistical software (V. 9.3; SAS Institute Inc.; Cary, NC, USA).

Data from the cell studies are presented as the mean \pm standard error (SEM) of six independent cultures for each patient per variable. Six patients of each sex were examined for the cell-hormone treatment study. Statistical significance was determined by ANOVA with post hoc Bonferroni modification of Student's $t$ test. For graphs labeled as treatment over control, the value of each sample from the treated group was divided by the mean of the control group. Each data point represents the mean \pm SEM for six normalized values. The control is represented by a dashed line with a value equal to 1 . Significance was determined by using the MannWhitney test. Significance was reached when $p$ value was less than 0.05 . 


\section{Results}

\section{Histology}

Histology confirmed the radiographic diagnosis of severe OA. The articular cartilage was fibrillated and exhibited marked loss of sulfated glycosaminoglycans (sGAGs) (Fig. 1c).

\section{Synovial fluid}

Synovial fluid composition differed between men and women patients (Table 4). Men had increased levels of MMPs 1, 7, 9, and 13. Hepatocyte growth factor (HGF), stem cell factor (SCF), and stem cell growth factor beta $(\mathrm{SCGF} \beta)$ were all higher in male synovial fluid than in the synovial fluid of women patients. The amounts of sGAG, TGF $\beta 1$, and TGF $\beta 2$ were higher in men compared with women. Women had higher levels of inflammatory cytokines, IL2 $\alpha$, IL3, IL12p40, IL16, IL18, and TNF $\beta$, and chondrocyte apoptosis-inducing factor (TRAIL) compared with men. Higher levels of macrophage stimulators (leukemia inhibitory factor [LIF], macrophage colony-stimulating factor [M-CSF], macrophage migration inhibitory factor $[\mathrm{MIF}])$, and pro-inflammatory

Table 4 Levels of inflammatory cytokines measured in synovial fluid

\begin{tabular}{|c|c|c|c|c|}
\hline & \multicolumn{2}{|c|}{ Mean value $(\mathrm{pg} / \mathrm{ml}) \pm \mathrm{SEM}$} & \multirow[b]{2}{*}{$p$ value } & \\
\hline & Male & Female & & \\
\hline HGF & $1075.00 \pm 254.20$ & $514.30 \pm 46.10$ & 0.0352 & \multirow{14}{*}{ - Males $>$ females } \\
\hline IFN-a2 & $279.30 \pm 50.09$ & $159.80 \pm 12.10$ & 0.0207 & \\
\hline IL $1 \mathrm{a}$ & $389.00 \pm 23.91$ & $337.40 \pm 9.80$ & 0.0367 & \\
\hline MMP-1 & $2219.00 \pm 539.60$ & $1270.00 \pm 84.74$ & 0.049 & \\
\hline MMP-2 & $1981.00 \pm 50.44$ & $1811.00 \pm 42.84$ & 0.0248 & \\
\hline MMP-7 & $1189.00 \pm 15.21$ & $1147.00 \pm 7.63$ & 0.0173 & \\
\hline MMP-9 & $1565.00 \pm 473.20$ & $585.60 \pm 135.50$ & 0.0328 & \\
\hline MMP-12 & $39.20 \pm 0.87$ & $36.90 \pm 0.46$ & 0.0227 & \\
\hline MMP-13 & $441.90 \pm 18.22$ & $396.00 \pm 7.241$ & 0.0187 & \\
\hline SCF & $478.00 \pm 116.2$ & $239.80 \pm 21.45$ & 0.0487 & \\
\hline SCGF- $\beta$ & $5503.00 \pm 1713.20$ & $1928.00 \pm 433.60$ & 0.0487 & \\
\hline TGF $\beta 1$ & $1723.00 \pm 282.00$ & $1070.00 \pm 109.00$ & 0.0464 & \\
\hline TGF $\beta 2$ & $35.79 \pm 4.72$ & $23.69 \pm 2.74$ & 0.0415 & \\
\hline sGAG & $14.04 \pm 2.02$ & $6.25 \pm 0.57$ & 0.004 & \\
\hline GRO-a & $459.40 \pm 95.18$ & $739.80 \pm 61.36$ & 0.0217 & \multirow{12}{*}{ - Females $>$ males } \\
\hline IL2a & $843.90 \pm 166.50$ & $1321.00 \pm 120.20$ & 0.0306 & \\
\hline IL3 & $806.90 \pm 204.80$ & $1289.00 \pm 55.29$ & 0.0395 & \\
\hline IL12p40 & $380.60 \pm 81.14$ & $578.20 \pm 26.41$ & 0.0342 & \\
\hline IL16 & $708.10 \pm 148.50$ & $1353.00 \pm 247.00$ & 0.0449 & \\
\hline LIF & $309.60 \pm 60.31$ & $480.80 \pm 41.60$ & 0.0294 & \\
\hline MCP-3 & $147.70 \pm 29.88$ & $220.10 \pm 17.42$ & 0.0466 & \\
\hline M-CSF & $748.80 \pm 161.60$ & $1156.00 \pm 107.00$ & 0.0468 & \\
\hline MIF & $752.60 \pm 172.70$ & $1665.00 \pm 357.50$ & 0.0323 & \\
\hline MIG & $1793.00 \pm 321.80$ & $4252.00 \pm 1018.00$ & 0.0371 & \\
\hline TNF- $\beta$ & $148.00 \pm 42.95$ & $252.20 \pm 8.99$ & 0.0304 & \\
\hline TRAIL & $714.90 \pm 156.20$ & $1100.00 \pm 79.97$ & 0.0332 & \\
\hline$\beta-N G F$ & $5.67 \pm 2.76$ & $3.42 \pm 0.83$ & 0.4791 & \multirow{7}{*}{ - Not significant } \\
\hline CTACK & $613.00 \pm 112.90$ & $925.30 \pm 172.90$ & 0.1621 & \\
\hline IL18 & $156.80 \pm 8.56$ & $160.90 \pm 7.90$ & 0.727 & \\
\hline $\operatorname{IL} 1 \beta$ & $214.70 \pm 99.25$ & $128.80 \pm 13.42$ & 0.4113 & \\
\hline MMP-3 & $2898.00 \pm 81.25$ & $2961.00 \pm 100.4$ & 0.6544 & \\
\hline MMP-8 & $1183.00 \pm 310.20$ & $985.50 \pm 103.40$ & 0.4934 & \\
\hline SDF-1a & $506.50 \pm 79.08$ & $461.70 \pm 51.30$ & 0.6259 & \\
\hline
\end{tabular}


mediators (growth-regulated oncogene $\alpha$ [GRO- $\alpha$ ], monocyte chemotactic protein-3 [MCP-3], and monokine induced by gamma interferon [MIG]) were found in women compared with men.

No sex-specific differences in the concentration of $1,25(\mathrm{OH})_{2} \mathrm{D}_{3}$ in synovial fluid were detected (Fig. 2a). Compared to men, women had less $25(\mathrm{OH}) \mathrm{D}_{3} ; 25(\mathrm{OH}) \mathrm{D}_{3}+$ $25(\mathrm{OH}) \mathrm{D}_{2}+24,25(\mathrm{OH})_{2} \mathrm{D}_{3}$; and calculated $24,25(\mathrm{OH})_{2} \mathrm{D}_{3}$ $+25(\mathrm{OH}) \mathrm{D}_{2}$ in the synovial fluid (Fig. $2 \mathrm{~b}-\mathrm{d}$ ); however, mass spectroscopy detected no differences in the levels of $24,25(\mathrm{OH})_{2} \mathrm{D}_{3}$ between women and men (Fig. 2e).

\section{Chondrocyte cultures}

Chondrocytes expressed mRNAs for both receptors for $1,25(\mathrm{OH})_{2} \mathrm{D}_{3}$ (nVDR and PDIA3) and for ER $\alpha 66$ (ESR1) and ER 36 (Fig. 3a-d, respectively). Female chondrocytes from minimally fibrillated cartilage had less VDR mRNA than male cells but comparable levels of mRNAs for the other three receptors. Female cells isolated from eroded cartilage had less nVDR mRNA, less PDIA3 mRNA, and more ESR1 mRNA than male cells.

mRNAs for inflammatory cytokines were elevated in male cells from eroded cartilage compared to cells from minimally fibrillated cartilage (Fig. 3e-h). In contrast, female cells exhibited no differences in IL1A or IL1B mRNAs and expression of IL6 and IL8 was reduced in the female erosion cells compared with the minimally fibrillated cells. Female cells from minimally fibrillated cartilage had higher expression of IL1A, IL6, and IL8 than male cells from similar cartilage. No difference in expression of the anti-inflammatory cytokine IL10 was evident between male and female cells or as a function of the type of cartilage from which the cells were isolated (Fig. 3i).

Sex-specific differences in expression of WNT signaling molecules were observed, particularly in chondrocytes isolated from erosion cartilage. WNT3A, CTNNB, DKK2, and DKK2 were all expressed to a greater extent in male erosion cells than in cells from minimally eroded
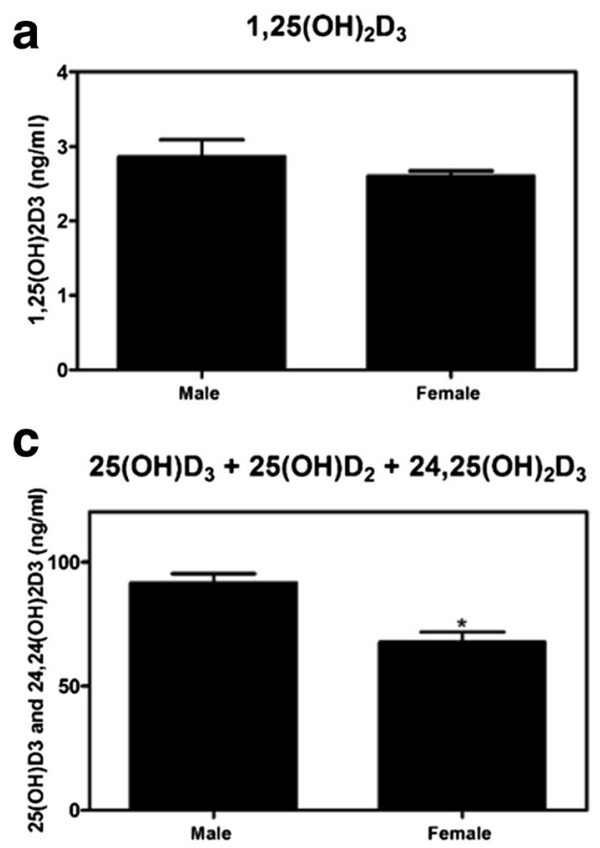

e

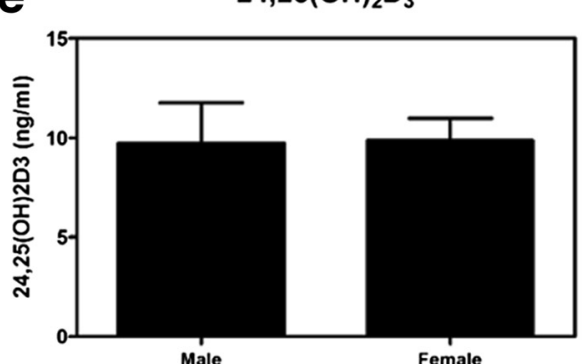

\section{b $25(\mathrm{OH}) \mathrm{D}_{3}$}

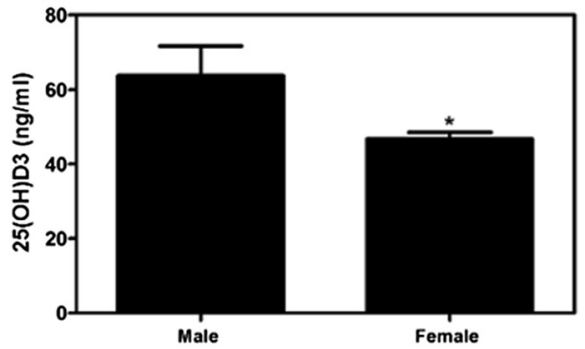

d

Calculated 24,25(OH) $)_{2} \mathrm{D}_{3}+25(\mathrm{OH}) \mathrm{D}_{2}$

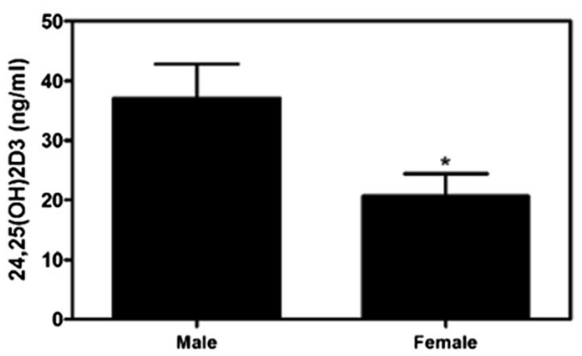

Fig. 2 Vitamin D metabolites in synovial fluid. a-d Levels of vitamin D metabolites in the synovial fluid of 10 males and 10 females undergoing total joint arthroplasty were measured using ELISA and (e) mass spectrometry. ${ }^{*} p<0.05$ compared with male 


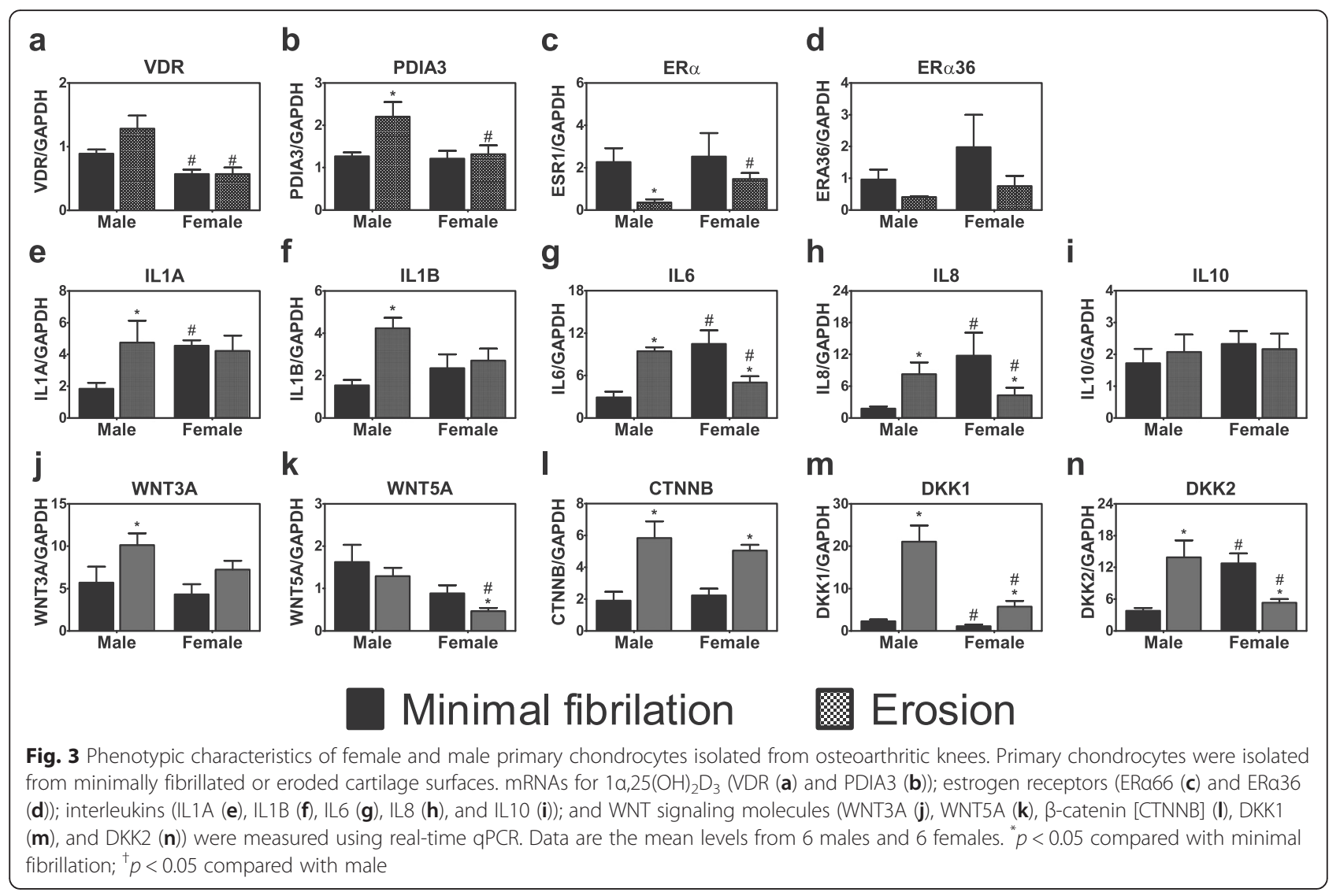

tissues (Fig. 3j, l-n). This was also the case for CTNNB and DKK1 in cells from female erosion tissue compared with minimally fibrillated female cells (Fig. 3l, m). However, WNT5A (Fig. 3k) and DKK2 (Fig. 3n) were reduced in female erosion tissue compared with minimally fibrillated tissue, and the levels of these two mRNAs were significantly lower than seen in male cells from similar tissues.

Chondrocytes responded to stimulation by vitamin D metabolites in a sex-specific manner. Male cells exhibited a more robust increase in alkaline phosphatase activity in

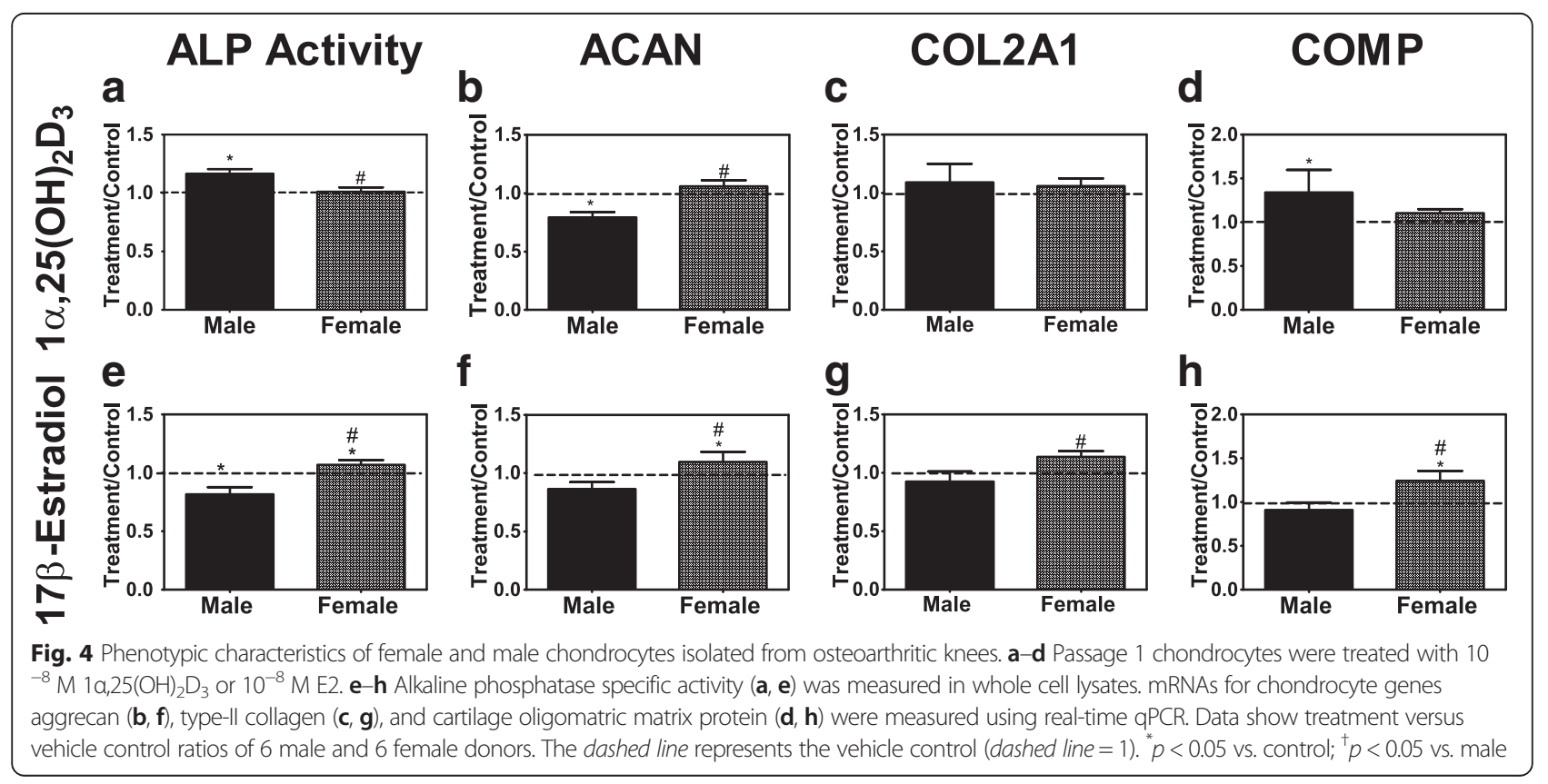


response to $1 \alpha, 25(\mathrm{OH})_{2} \mathrm{D}_{3}$ than female cells (Fig. 4a), but expression of ACAN was reduced (Fig. 4b). No sex-specific differences in expression of COL2A1 or COMP were observed (Fig. 4c, d). 24R,25(OH) ${ }_{2} \mathrm{D}_{3}$ inhibited alkaline phosphatase activity in female chondrocyte cultures compared with control cells and compared with male cells (Additional file 2: Figure $\mathrm{S} 1 \mathrm{~A}) .24 \mathrm{R}, 25(\mathrm{OH})_{2} \mathrm{D}_{3}$ had a stimulatory effect on male cells compared with control cultures and to female cells treated with the vitamin $\mathrm{D}$ metabolite (Additional file 2: Figure S1B). $24 \mathrm{R}, 25(\mathrm{OH})_{2} \mathrm{D}_{3}$ affected male and female cells comparably with respect to COL2A1 (increase) or COMP (decrease) (Additional file 2: Figure S1C, D).

E2 reduced alkaline phosphatase activity in male chondrocytes and stimulated it in female cells (Fig. 4e). E2 had no effect on expression of ACAN, COL2A1, or COMP in male cells, but it increased expression of all three mRNAs in female cells (Fig. 4f-h). DHT reduced alkaline phosphatase activity in male cells but had no effect on the enzyme in female cells (Additional file 2: Figure S1E). DHT had no effect on expression of ACAN, COL2A1, or COMP in cells of either sex (Additional file 2: Figure S1F-H).

\section{Osteoblast cultures}

Male osteoblasts from erosion tissue expressed high levels of nVDR compared with minimally fibrillated male cells or with female cells from either site (Fig. 5a). No differences in expression of PDIA3 were observed (Fig. 5b). Female erosion cells expressed more ESR1 (ER $\alpha)$ and female minimally fibrillated osteoblasts expressed more ER $\alpha 36$ than male cells (Fig. 5c, d); however, no differences in expression of either E2 receptor were seen as a function of the tissue source for either males or females.

In male osteoblasts, $1 \alpha, 25(\mathrm{OH})_{2} \mathrm{D}_{3}$, increased alkaline phosphatase activity (Fig. 6a) and osteocalcin production (Fig. 6b) but decreased levels of osteoprotegerin (Fig. 6c). $1 \alpha, 25(\mathrm{OH})_{2} \mathrm{D}_{3}$ had no effect on alkaline phosphatase activity in female cells, but its stimulatory effect on osteocalcin and inhibitory effect on osteoprotegerin were comparable to that seen in male cells. E2 inhibited alkaline phosphatase activity in male cells (Fig. 6d). It had no effect on enzyme activity in female osteoblast, but it stimulated osteocalcin production in the female cells (Fig. 6e), and it inhibited osteoprotegerin production (Fig. 6f). In contrast, DHT increased alkaline phosphatase activity in male osteoblasts (Additional file 3: Figure S2A), increased osteocalcin production (Additional file 3: Figure $\mathrm{S} 2 \mathrm{~B}$ ), and reduced osteoprotegerin production (Additional file 3: Figure S2C). Female cells exhibited increased osteoprotegerin production in response to DHT.
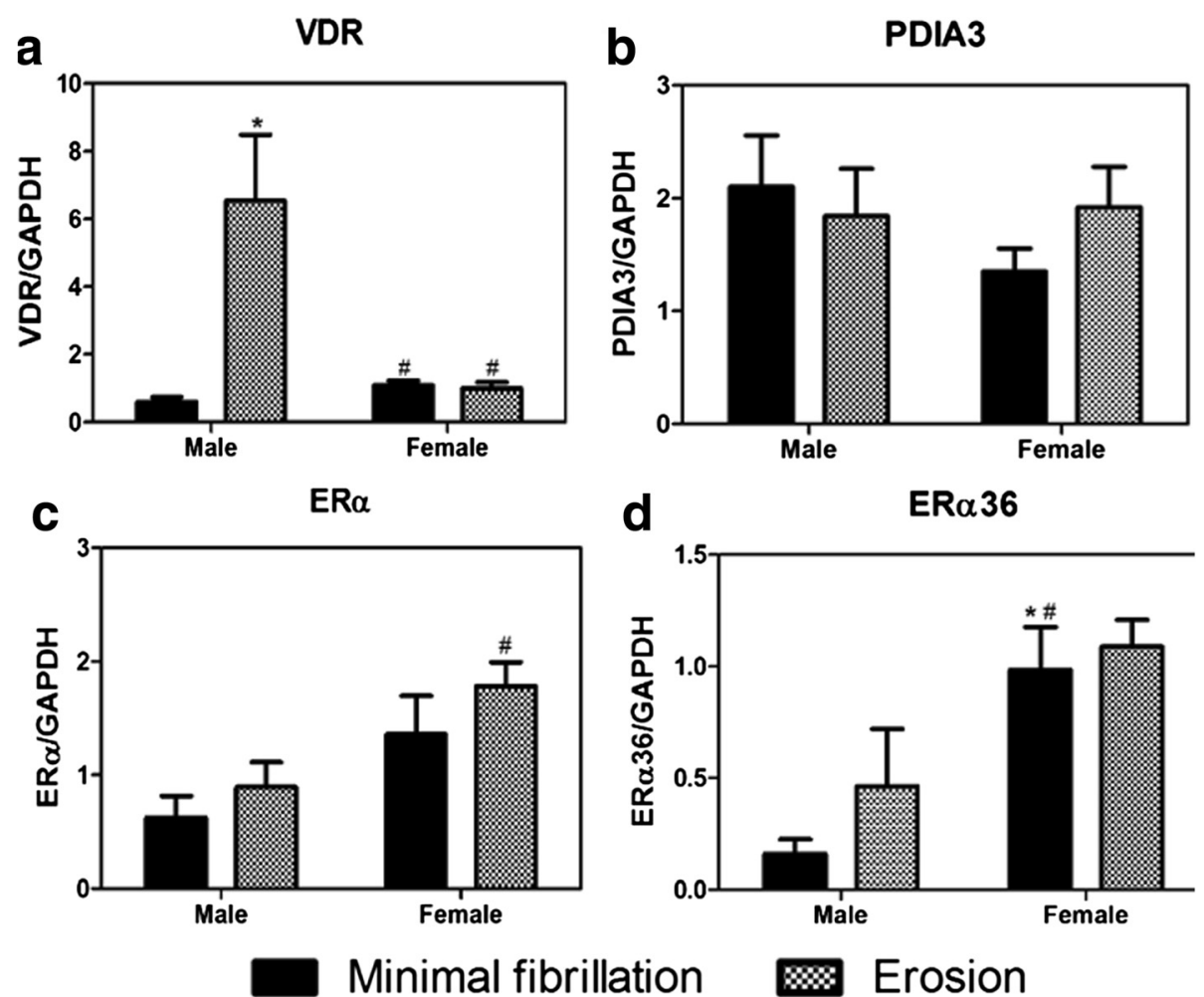

Fig. 5 Phenotypic characteristics of female and male primary osteoblasts isolated from osteoarthritic knees. Female and male primary osteoblasts were isolated from subchondral bone. mRNAs for $1 a, 25(\mathrm{OH})_{2} \mathrm{D}_{3}$ (VDR (a) and PDIA3 (b)) and estrogen receptors ERa66 (ERa (c)) and ERa36 (d) were measured using real-time $\mathrm{qPCR}$. Data are the mean \pm SEM of 6 males and 6 females. ${ }^{*} p<0.05 \mathrm{vs}$. minimal fibrillation; ${ }^{\dagger} p<0.05$ vs. male 


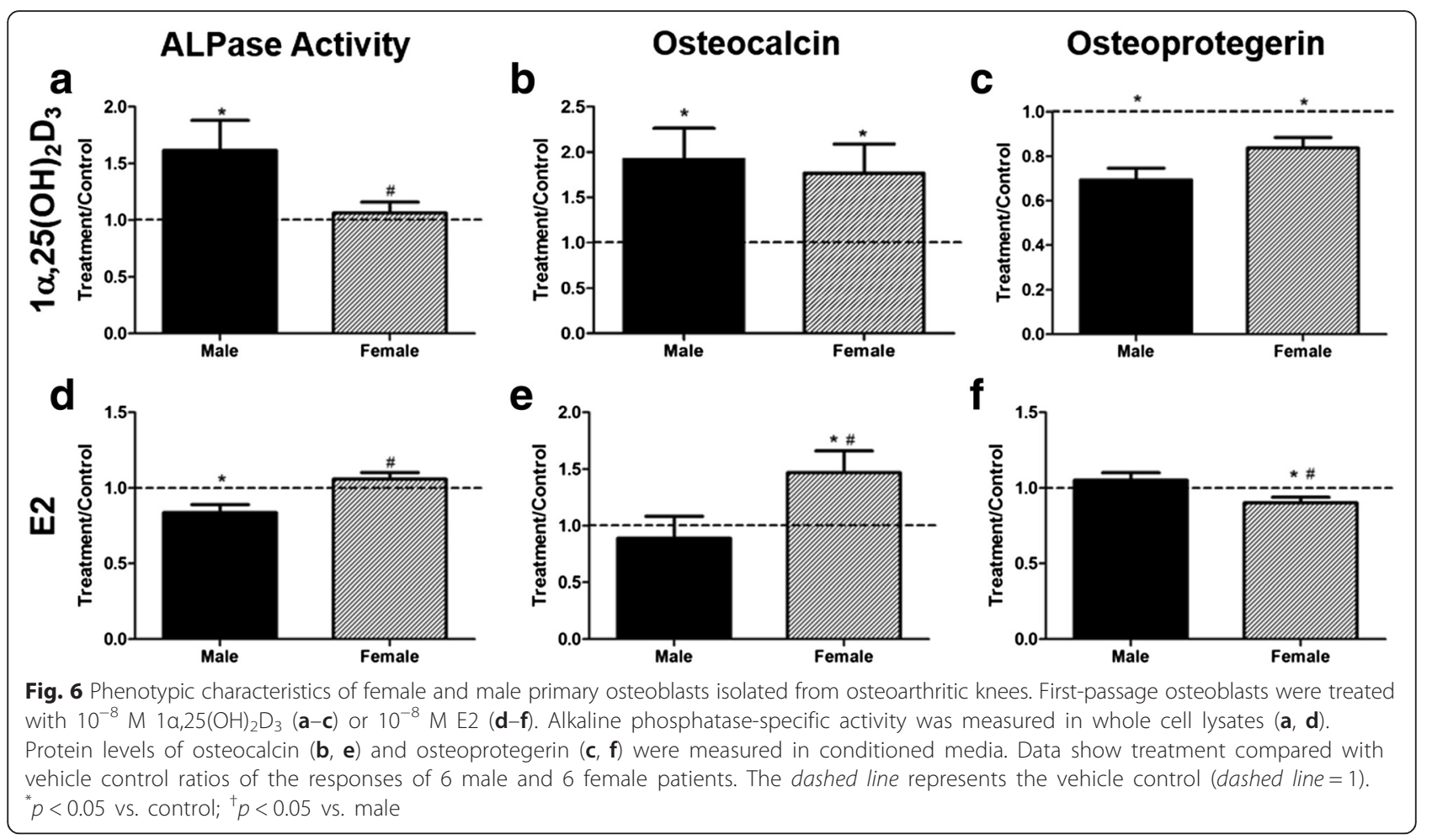

\section{Discussion}

Rather than investigating an underlying sex-dependent mechanism in the etiology of OA, the goal of this study was to screen a broad range of variables in tissues and fluids obtained during TKA to investigate whether there are sex differences in knee tissues affected by OA. The severity of $\mathrm{OA}$ in men and women study patients was comparable. Thus, detected differences could be ascribed to underlying sex-dependent traits rather than differences in disease status. Our results demonstrated that sex differences are present in OA-affected tissues. Not only were there differences in the composition of synovial fluid between the sexes, but chondrocytes and osteoblasts isolated from OA-affected cartilage and bone differed in a sex-dependent manner with respect to expression of hormone receptors and responded differentially to $1 \alpha, 25(\mathrm{OH})_{2} \mathrm{D}_{3}, 24 \mathrm{R}, 25(\mathrm{OH})_{2} \mathrm{D}_{3}$, E2, and DHT. Moreover, articular chondrocytes from men and women patients exhibited sex differences in their expression of genes for inflammatory cytokines, enzymes involved in matrix degradation, and WNT signaling molecules involved in regulation of proliferation and differentiation.

Our patient population exhibited few clinical differences between men and women. There was no evidence of a difference in serum $25(\mathrm{OH}) \mathrm{D}_{3}$ levels, radiographic assessment, knee pain, or areas of knee pain prior to surgery between women and men. This could be due to the advanced stage of disease in our study population. Studies of younger patients have shown sex differences in knees with OA, with articular cartilage surface areas being $17.5 \%$ to $23.5 \%$ lower in women than in men [36], which supports the idea that sex differences contribute to disease progression, but once the advanced disease is established, sex differences are less important.

We did observe some clinical differences in the study patient population that were sex dependent. The painpressure threshold $1 \mathrm{~cm}$ above the medial joint line was lower in women than in men; however, the clinical significance of this is unclear. We did not test the painpressure threshold of anatomic regions outside the medial knee, and further study is warranted. We also found that women were more likely to have used or were using vitamin D and estrogen supplements compared with men. Studies have linked estrogen supplementation with reduced risk of OA, which could explain how a drop in estrogen in postmenopausal women could contribute to the severity of OA found in women $[8,37,38]$ compared with males. Together, these data suggest that future studies should include younger postmenopausal women and age-matched men to better assess sex differences in their disease severity.

The synovial fluid composition was affected by the genetic sex of the patient in a number of ways. Men had higher levels of MMPs, the primary enzymes responsible for the degradation of cartilage, and HGF, which is synthesized by osteoblasts from the subchondral bone plate and produced at a higher rate by OA osteoblasts [39]. However, men had higher levels of growth factors, including TGF $\beta \mathrm{s}$, SCF (stem cell factor), and SCGF $\beta$ 
(stem cell growth factor beta), and sGAGs compared with females, which have been shown to protect articular cartilage from degradation [40-42]. These results suggest that men may be more resistant to OA; although men had higher levels of matrix degradation enzymes, they also had more protective and growth-inducing factors that could aid in the repair and remodeling processes. Women had higher levels of inflammatory cytokines, especially IL18, which induces the production of PGE2 [43]. This is corroborated by studies showing that women experience more pain [6]. Women had less protective factors, which could explain their increased disease severity as they lose the protective effect of estrogen after menopause.

Vitamin D metabolites play important roles in skeletal development [44] and in maintaining cartilage and bone homeostasis $[45,46]$. The ELISA kit used to measure $1,25(\mathrm{OH})_{2} \mathrm{D}_{3}$, a metabolite of $25(\mathrm{OH}) \mathrm{D}_{3}$ associated with $\mathrm{Ca}++$ homeostasis as well as terminal differentiation of chondrocytes and osteoblasts [47-49], did not detect a difference in the synovial fluid levels between men and women. Because a suitable kit does not exist for measuring $24,25(\mathrm{OH})_{2} \mathrm{D}_{3}$, a metabolite associated with chondrocyte proliferation and resistance to apoptotic stimuli [50], we compared results using two kits, one that measured $25(\mathrm{OH}) \mathrm{D}_{3}$ alone and one that measured $25(\mathrm{OH}) \mathrm{D}_{3}$, $25(\mathrm{OH}) \mathrm{D}_{2}$, and $24,25(\mathrm{OH})_{2} \mathrm{D}_{3}$. Both kits identified reduced vitamin $\mathrm{D}$ metabolites in female synovial fluid, suggesting a possible reduction in $24,25(\mathrm{OH})_{2} \mathrm{D}_{3}$. However, when $24,25(\mathrm{OH})_{2} \mathrm{D}_{3}$ was measured directly by a commercial lab using mass spectroscopy, no sex difference was found. None of these methods is definitive, but taken together, they show a clear and reproducible finding that synovial vitamin $\mathrm{D}$ metabolites are regulated in a sex-dependent manner.

Studies using growth plate chondrocytes and healthy human articular chondrocytes have shown that the numbers of receptors vary in a sex-specific manner [11, 29, 51]. Our results examining gene expression also demonstrated sex-dependent differences. Chondrocytes from male erosion tissue and minimally fibrillated tissue expressed higher levels of mRNAs for the nuclear VDR whereas receptors for ER 666 (ESR1) were lower in cells from male erosion tissue than from female erosion tissue. Osteoblasts from male erosion tissue subchondral bone exhibited higher nuclear VDR expression, and female osteoblasts had higher ESR1 than male cells. We also found that male chondrocytes and osteoblasts were more responsive to $1 \alpha, 25(\mathrm{OH})_{2} \mathrm{D}_{3}$ treatment than female cells. Previously, studies have shown that male osteoblasts have a more robust response to $1 \alpha, 25(\mathrm{OH})_{2} \mathrm{D}_{3}$ [52], which supports our findings. Female cells were more responsive to estrogen treatment compared with male cells, which is supported by their greater expression of estrogen receptor mRNAs. The study results are supported by our previous observations using articular chondrocytes from young healthy men without OA, which showed that male cells had no response to E2 whereas female chondrocytes exhibited a marked response to E2 [29]. Studies have shown that chondrogenic progenitor cells respond differently to estrogen and testosterone in repairing OA cartilage, suggesting sexual dimorphism exists in cell-repair mechanisms in OA [53]. Collectively, our data suggest that the difference in the levels of VDR and PDIA3 and local and circulating $25(\mathrm{OH}) \mathrm{D}_{3}$ between men and women, could contribute to the more prevalent and severe cases of OA found in women.

Chondrocytes isolated from both erosion cartilage and minimally fibrillated cartilage exhibited sex-specific phenotypic traits. In addition to differences in receptor expression, there were a number of differences with respect to expression of mRNAs for pro-inflammatory cytokines. The level of these cytokines was comparable for eroded cartilage cells regardless of sex; however, in minimally fibrillated cartilage cells, women had higher levels of pro-inflammatory cytokines compared with men. This suggests that female chondrocytes may produce higher levels of inflammatory cytokines at an earlier stage of OA. Interestingly, the anti-inflammatory cytokine IL10 was expressed at comparable levels in cells from men and women irrespective of tissue source.

Expression of mRNAs for WNT family genes varied in a sex-specific manner as well, but the interpretation of these data will require further experimentation. Higher levels of WNT antagonists are suggested to inhibit chondrocyte hypertrophy. DKK1 inhibits MMP-13 and ADAMTS-4 expression in chondrocytes in response to WNT3a treatment [54]. Activation of $\mathrm{WNT} / \beta$-catenin signaling in primary human chondrocytes inhibits basal IL1 $\beta$-stimulated increases in MMP-1, -3 , and -13 levels, possibly through inhibition of $\mathrm{NF}_{\mathrm{K} B}$ signaling $[55,56]$. Men had higher levels of WNT signaling molecules, which is consistent with our findings that although men had higher levels of MMPs, they may be more resistant to OA as they also had more factors that are protective.

The underlying etiology of OA is not well understood. It has been hypothesized that mechanical instabilities lead to changes in the biomechanical properties of the articular cartilage and, ultimately, in the biochemical properties of the cells and extracellular matrix [7]. Recent data indicate that there are sex-specific differences at the molecular and cellular level that may exacerbate the effects of altered mechanical load [57-60]. Our data do not address disease etiology. While they do support the hypothesis that sex differences exist, all patients had advanced OA. Thus, it is not possible to attribute specific differences to a clinical outcome. It is possible, however, that sex differences may have contributed to differences in disease progression that led to the need for TKA. 
This study had a number of limitations. We used passage 1 cells in our study to investigate the effect of hormone treatments on the cells. Human chondrocytes lose phenotypic traits when subpassaged, so it is preferable to use primary cells. Unfortunately, the number of primary cells was limited, necessitating the need for culture expansion. In a series of preliminary studies, we found that the first-passage cells expressed similar levels of chondrocyte and osteoblast markers to primary cells (data not shown). One of the limitations of our studies is that we could not get tissues from healthy human knees as a control; however, we addressed the limitation by using cartilage and subchondral bone from areas that showed minimal articular fibrillation.

\section{Conclusions}

In this study, we identified sex-specific differences in synovial fluid, chondrocytes, and osteoblasts in advanced human knee OA tissues. Our understanding of such sexspecific differences is still very early, and additional research is needed. Understanding such sex differences in knee OA may allow for the introduction of sex-specific therapies and new treatment avenues for patients experiencing this often disabling condition.

\section{Additional files}

Additional file 1: Table S1. Primers for real-time PCR. (DOCX $16 \mathrm{~kb}$ )

Additional file 2: Figure S1. Phenotypic characteristics of female and male chondrocytes isolated from osteoarthritic knees. First-passage chondrocytes were treated with $10^{-7} \mathrm{M} 24 \mathrm{R}, 25(\mathrm{OH})_{2} \mathrm{D}_{3}$ (A-D) or $10^{-8} \mathrm{M}$ $\mathrm{DHT}(\mathrm{E}-\mathrm{H})$. Alkaline phosphatase-specific activity $(\mathrm{A}, \mathrm{D})$ was measured in whole cell lysates. mRNAs for chondrocyte genes aggrecan (B, F), type-II collagen $(C, G)$, and cartilage oligomeric matrix protein $(D, H)$ were measured using real-time $\mathrm{qPCR}$. Data show treatment compared with vehicle control ratios of the responses of 6 male and 6 female patients. The dashed line represents the vehicle control (dashed line $=1$ ). ${ }^{*} p<0.05$ vs. control; ${ }^{\dagger} p<0.05$ vs. male. (TIF $1363 \mathrm{~kb}$ )

Additional file 3: Figure S2. Phenotypic characteristics of female and male primary osteoblasts isolated from osteoarthritic knees. First-passage osteoblasts were treated with $10^{-8} \mathrm{M} \mathrm{DHT}$. Alkaline phosphatase-specific activity (A) was measured in whole cell lysates. Protein levels of osteocalcin (B) and osteoprotegerin (C) were measured in conditioned media. Data show treatment compared with vehicle control ratios of the responses of 6 male and 6 female patients. The dashed line represents the vehicle control (dashed line = 1). ${ }^{*} p<0.05$ vs. control; ${ }^{\dagger} p<0.05$ vs. male. (TIF 1003 kb)

\section{Abbreviations}

sGAG: sulfated glycosaminoglycan; E2: 17ß-estradiol;

$\mathrm{DHT}$ : dihydrotestosterone; $1 \mathrm{a}, 25(\mathrm{OH})_{2} \mathrm{D}_{3}$ : 1-alpha,25-dihydroxyvitamin $\mathrm{D} 3$; 24R,25(OH) $2 \mathrm{D}_{3}$ : 24R,25-dihydroxyvitamin D3; VDR: canonical vitamin D receptor; PDIA3: protein disulfide isomerase family $A$ member 3; ERa66: canonical estrogen receptor a; ERa36: shorter variant estrogen receptor; OA: osteoarthritis; HGF: hepatocyte growth factor; SCF: stem cell factor; SCGF $\beta$ : stem cell growth factor beta; TGF $\beta$ : transforming growth factor beta; TNFa and TNF $\beta$ : tumor necrosis factor alpha and beta; MIF: macrophage migration inhibitory factor; WNT: wingless-related integrated site a family of signaling molecules; DKK1: Dickkopf-1; IL1a etc.: interleukin-1 alpha; ACAN: mRNA for aggrecan; COL2A1: mRNA for type-II collagen alpha 1 chain; COMP: mRNA for cartilage oligomeric matrix protein; MMP: matrix metalloproteinase; TRAIL: TNF-related apoptosis-inducing ligand;
LIF: leukemia inhibitory factor; M-CSF: macrophage colony-stimulating factor; GRO-a: growth-regulated oncogene a; MCP-3: monocyte chemotactic protein3; MIG: monokine induced by gamma interferon; CTNNB: mRNA for betacatenin; TKA: total knee arthroplasty; SF-12: Short Form-12 Health Survey; WOMAC: Western Ontario \& McMaster Universities Arthritis Index; PASE: Physical Activity Scale for the Elderly; OARSI-OMERACT: Osteoarthritis Research Society International-Outcome Measures in Rheumatology pain scale.

\section{Acknowledgements}

We thank Colleen Thomas at Mayo Clinic with help on statistical analyses of the clinical data. We also thank Dr. David Hart (University of Calgary) and Dr. Karen Berkley (Florida State University) for their contributions to the design of the studies. This work was supported by a grant from the Society for Women's Health Research ISIS Network for Musculoskeletal Health and funding from Children's Healthcare of Atlanta, the Price Gilbert, Jr.

Foundation, the US Department of Defense, and the National Institutes of Health.

\section{Authors' contributions}

This work represents partial completion of the PhD thesis for QP. QP and RON performed the cell culture assays; SLH catalogued all samples and assisted in the data analysis; QP wrote the original draft of the manuscript; MIO performed all clinical assessments and surgeries; RDC performed a review of the clinical data; $\mathrm{BDB}$ and $\mathrm{ZS}$ analyzed the results; $\mathrm{BDB}, \mathrm{ZS}$, and $\mathrm{MIO}$ edited the manuscript. All authors read and approved the final manuscript.

\section{Competing interests}

The authors declare that they have no competing interests.

\section{Author details}

${ }^{1}$ Department of Mechanical Engineering, Georgia Institute of Technology, Atlanta, GA, USA. ${ }^{2}$ Center for Musculoskeletal Care, Yale University School of Medicine, New Haven, CT, USA. ${ }^{3}$ Department of Orthopaedics, University of California at San Diego, San Diego, CA, USA. ${ }^{4}$ Department of Biomedical Engineering, Virginia Commonwealth University, Richmond, VA, USA.

${ }^{5}$ Department of Periodontics, University of Texas Health Science Center at San Antonio, San Antonio, TX, USA. ${ }^{6}$ Wallace H. Coulter Department of Biomedical Engineering, Georgia Institute of Technology, Atlanta, GA, USA. ${ }^{7}$ School of Engineering, Virginia Commonwealth University, 601 West Main Street, Suite 331, Richmond, VA 23284, USA.

Received: 17 February 2016 Accepted: 12 May 2016

Published online: 02 June 2016

\section{References}

1. Murphy L, Schwartz TA, Helmick CG, Renner JB, Tudor G, Koch G, et al. Lifetime risk of symptomatic knee osteoarthritis. Arthritis Rheum. 2008:59:1207-13.

2. Valderrabano V, Steiger C. Treatment and prevention of osteoarthritis through exercise and sports. J Aging Res. 2010;2011:374653.

3. Richette P, Corvol M, Bardin T. Estrogens, cartilage, and osteoarthritis. Joint Bone Spine. 2003:70:257-62.

4. Bay-Jensen AC, Slagboom E, Chen-An P, Alexandersen P, Qvist P Christiansen C, et al. Role of hormones in cartilage and joint metabolism: understanding an unhealthy metabolic phenotype in osteoarthritis. Menopause. 2013;20:578-86

5. Theis KA, Helmick CG, Hootman JM. Arthritis burden and impact are greater among U.S. women than men: intervention opportunities. J Womens Health (Larchmt). 2007:16:441-53.

6. Sluka KA, Berkley KJ, O'Connor MI, Nicolella DP, Enoka RM, Boyan BD, et al. Neural and psychosocial contributions to sex differences in knee osteoarthritic pain. Biol Sex Differ. 2012;3:26,6410-3-26.

7. Nicolella DP, O'Connor MI, Enoka RM, Boyan BD, Hart DA, Resnick E, et al. Mechanical contributors to sex differences in idiopathic knee osteoarthritis. Biol Sex Differ. 2012;3:28,6410-3-28.

8. Ham KD, Loeser RF, Lindgren BR, Carlson CS. Effects of long-term estrogen replacement therapy on osteoarthritis severity in cynomolgus monkeys. Arthritis Rheum. 2002;46:1956-64.

9. Ma HL, Blanchet TJ, Peluso D, Hopkins B, Morris EA, Glasson SS. Osteoarthritis severity is sex dependent in a surgical mouse model. Osteoarthritis Cartilage. 2007;15:695-700. 
10. Ekstein J, Nasatzky E, Boyan BD, Ornoy A, Schwartz Z. Growth-plate chondrocytes respond to 17beta-estradiol with sex-specific increases in IP3 and intracellular calcium ion signalling via a capacitative entry mechanism. Steroids. 2005;70:775-86.

11. Elbaradie K, Wang Y, Boyan BD, Schwartz Z. Rapid membrane responses to dihydrotestosterone are sex dependent in growth plate chondrocytes. J Steroid Biochem Mol Biol. 2012;132:15-23.

12. Sylvia VL, Hughes T, Dean DD, Boyan BD, Schwartz Z. 17beta-estradiol regulation of protein kinase $C$ activity in chondrocytes is sex-dependent and involves nongenomic mechanisms. J Cell Physiol. 1998;176:435-44.

13. Ornoy A, Suissa M, Yaffe P, Boyan BD, Schwartz Z. Gender-related effects of vitamin D metabolites on cartilage and bone. Bone Miner. 1994;27:235-47.

14. Schwartz Z, Finer Y, Nasatzky E, Soskolne WA, Dean DD, Boyan BD, et al. The effects of 17 beta-estradiol on chondrocyte differentiation are modulated by vitamin D3 metabolites. Endocrine. 1997;7:209-18.

15. Olivares-Navarrete R, Hyzy SL, Chaudhri RA, Zhao G, Boyan BD, Schwartz Z. Sex dependent regulation of osteoblast response to implant surface properties by systemic hormones. Biol Sex Differ. 2010;1:4.

16. Bouillon R, Suda T. Vitamin D: calcium and bone homeostasis during evolution. Bonekey Rep. 2014;3:480.

17. St-Arnaud R. The direct role of vitamin D on bone homeostasis. Arch Biochem Biophys. 2008;473:225-30.

18. Ornoy A, Goodwin D, Noff D, Edelstein S. 24, 25-dihydroxyvitamin D is a metabolite of vitamin D essential for bone formation. Nature. 1978;276:517-9.

19. St-Arnaud R, Naja RP. Vitamin D metabolism, cartilage and bone fracture repair. Mol Cell Endocrinol. 2011;347:48-54.

20. Holick MF. Vitamin D, deficiency. N Engl J Med. 2007;357:266-81.

21. Felson DT, Niu J, Clancy M, Aliabadi P, Sack B, Guermazi A, et al. Low levels of vitamin $D$ and worsening of knee osteoarthritis: results of two longitudinal studies. Arthritis Rheum. 2007;56:129-36.

22. Castillo EC, Hernandez-Cueto MA, Vega-Lopez MA, Lavalle C, Kouri JB, OrtizNavarrete V. Effects of Vitamin D Supplementation during the Induction and Progression of Osteoarthritis in a Rat Model. Evid Based Complement Alternat Med. 2012;2012:156563.

23. Sylvia VL, Gay I, Hardin R, Dean DD, Boyan BD, Schwartz Z. Rat costochondral chondrocytes produce 17 beta-estradiol and regulate its production by 1alpha,25(OH)(2)D(3). Bone. 2002;30:57-63.

24. Hawker GA, Davis AM, French MR, Cibere J, Jordan JM, March L, et al. Development and preliminary psychometric testing of a new OA pain measure-an OARSI/OMERACT initiative. Osteoarthritis Cartilage. 2008;16:409-14.

25. Thompson LR, Boudreau R, Hannon MJ, Newman AB, Chu CR, Jansen M, et al. The knee pain map: reliability of a method to identify knee pain location and pattern. Arthritis Rheum. 2009;61:725-31.

26. Vance CG, Rakel BA, Blodgett NP, DeSantana JM, Amendola A, Zimmerman $M B$, et al. Effects of transcutaneous electrical nerve stimulation on pain, pain sensitivity, and function in people with knee osteoarthritis: a randomized controlled trial. Phys Ther. 2012;92:898-910.

27. Rakel BA, Blodgett NP, Bridget Zimmerman M, Logsden-Sackett N, Clark C, Noiseux N, et al. Predictors of postoperative movement and resting pain following total knee replacement. Pain. 2012;153:2192-203.

28. Goldberg RL, Kolibas LM. An improved method for determining proteoglycans synthesized by chondrocytes in culture. Connect Tissue Res. 1990;24:265-75.

29. Kinney RC, Schwartz Z, Week K, Lotz MK, Boyan BD. Human articular chondrocytes exhibit sexual dimorphism in their responses to 17 betaestradiol. Osteoarthritis Cartilage. 2005;13:330-7.

30. Chaudhri RA, Olivares-Navarrete R, Cuenca N, Hadadi A, Boyan BD, Schwartz Z. Membrane estrogen signaling enhances tumorigenesis and metastatic potential of breast cancer cells via estrogen receptor-alpha36 (ERalpha36). J Biol Chem. 2012;287:7169-81.

31. Hyzy SL, Olivares-Navarrete R, Hutton DL, Tan C, Boyan BD, Schwartz Z. Microstructured titanium regulates interleukin production by osteoblasts, an effect modulated by exogenous BMP-2. Acta Biomater. 2013;9:5821-9.

32. Olivares-Navarrete R, Hyzy SL, Park JH, Dunn GR, Haithcock DA, Wasilewski $C E$, et al. Mediation of osteogenic differentiation of human mesenchymal stem cells on titanium surfaces by a Wnt-integrin feedback loop. Biomaterials. 2011;32:6399-411.

33. Walker JM. The bicinchoninic acid (BCA) assay for protein quantitation. Methods Mol Biol. 1994;32:5-8.

34. Olivares-Navarrete R, Gittens RA, Schneider JM, Hyzy SL, Haithcock DA, Ullrich PF, et al. Osteoblasts exhibit a more differentiated phenotype and increased bone morphogenetic protein production on titanium alloy substrates than on poly-ether-ether-ketone. Spine J. 2012;12:265-72.

35. Olivares-Navarrete R, Hyzy SL, Pan Q, Dunn G, Williams JK, Schwartz Z, et al. Osteoblast maturation on microtextured titanium involves paracrine regulation of bone morphogenetic protein signaling. J Biomed Mater Res A. 2015;103:1721-31.

36. Eckstein F, Siedek V, Glaser C, Al-Ali D, Englmeier KH, Reiser M, et al. Correlation and sex differences between ankle and knee cartilage morphology determined by quantitative magnetic resonance imaging. Ann Rheum Dis. 2004;63:1490-5.

37. Spector TD, Nandra D, Hart DJ, Doyle DV. Is hormone replacement therapy protective for hand and knee osteoarthritis in women?: The Chingford Study. Ann Rheum Dis. 1997;56:432-4.

38. Roman-Blas JA, Castaneda S, Largo R, Herrero-Beaumont G. Osteoarthritis associated with estrogen deficiency. Arthritis Res Ther. 2009;11:241.

39. Guevremont M, Martel-Pelletier J, Massicotte F, Tardif G, Pelletier JP, Ranger $P$, et al. Human adult chondrocytes express hepatocyte growth factor (HGF) isoforms but not HgF: potential implication of osteoblasts on the presence of HGF in cartilage. J Bone Miner Res. 2003;18:1073-81.

40. van Beuningen HM, van der Kraan PM, Arntz OJ, van den Berg WB. Does TGFbeta protect articular cartilage in vivo? Agents Actions Suppl. 1993;39:127-31.

41. Hannan N, Ghosh P, Bellenger C, Taylor T. Systemic administration of glycosaminoglycan polysulphate (arteparon) provides partial protection of articular cartilage from damage produced by meniscectomy in the canine. J Orthop Res. 1987:5:47-59.

42. Man C, Zhu S, Zhang B, Hu J. Protection of articular cartilage from degeneration by injection of transforming growth factor-beta in temporomandibular joint osteoarthritis. Oral Surg Oral Med Oral Pathol Oral Radiol Endod. 2009;108:335-40.

43. Futani H, Okayama A, Matsui K, Kashiwamura S, Sasaki T, Hada T, et al. Relation between interleukin-18 and PGE2 in synovial fluid of osteoarthritis: a potential therapeutic target of cartilage degradation. J Immunother. 2002; 25 Suppl 1:S61-4.

44. Idelevich A, Kerschnitzki M, Shahar R, Monsonego-Ornan E. 1,25(OH)2D3 alters growth plate maturation and bone architecture in young rats with normal renal function. PLoS One. 2011;6, e20772.

45. Ding C, Cicuttini F, Parameswaran V, Burgess J, Quinn S, Jones G. Serum levels of vitamin $D$, sunlight exposure, and knee cartilage loss in older adults: the Tasmanian older adult cohort study. Arthritis Rheum. 2009;60: 1381-9.

46. Klaus G, Meinhold-Heerlein R, Milde P, Ritz E, Mehls O. Effect of vitamin D on growth cartilage cell proliferation in vitro. Pediatr Nephrol. 1991;5:461-6.

47. Boyan BD, Schwartz Z, Swain LD. In vitro studies on the regulation of endochondral ossification by vitamin D. Crit Rev Oral Biol Med. 1992;3:15-30.

48. Boyan BD, Sylvia VL, Dean DD, Del Toro F, Schwartz Z. Differential regulation of growth plate chondrocytes by 1alpha,25-(OH)2D3 and 24R,25- $(\mathrm{OH}) 2 \mathrm{D} 3$ involves cell-maturation-specific membrane-receptor-activated phospholipid metabolism. Crit Rev Oral Biol Med. 2002;13:143-54.

49. Myrtle JF, Norman AW. Vitamin D: A cholecalciferol metabolite highly active in promoting intestinal calcium transport. Science. 1971;171:79-82.

50. Boyan BD, Hurst-Kennedy J, Denison TA, Schwartz Z. 24R,25dihydroxyvitamin D3 [24R,25(OH)2D3] controls growth plate development by inhibiting apoptosis in the reserve zone and stimulating response to 1alpha,25(OH)2D3 in hypertrophic cells. J Steroid Biochem Mol Biol. 2010; 121:212-6.

51. McMillan J, Fatehi-Sedeh S, Sylvia VL, Bingham V, Zhong M, Boyan BD, et al. Sex-specific regulation of growth plate chondrocytes by estrogen is via multiple MAP kinase signaling pathways. Biochim Biophys Acta. 2006;1763: 381-92.

52. Chen J, Olivares-Navarrete R, Wang Y, Herman TR, Boyan BD, Schwartz Z. Protein-disulfide isomerase-associated 3 (Pdia3) mediates the membrane response to 1,25-dihydroxyvitamin D3 in osteoblasts. J Biol Chem. 2010;285:37041-50.

53. Koelling S, Miosge N. Sex differences of chondrogenic progenitor cells in late stages of osteoarthritis. Arthritis Rheum. 2010;62:1077-87.

54. Oh $\mathrm{H}$, Chun $\mathrm{CH}$, Chun JS. Dkk-1 expression in chondrocytes inhibits experimental osteoarthritic cartilage destruction in mice. Arthritis Rheum. 2012;64:2568-78.

55. Bougault C, Priam S, Houard X, Pigenet A, Sudre L, Lories RJ, et al. Protective role of frizzled-related protein $B$ on matrix metalloproteinase induction in mouse chondrocytes. Arthritis Res Ther. 2014;16:R137. 
56. Leijten JC, Bos SD, Landman EB, Georgi N, Jahr H, Meulenbelt I, et al. GREM1, FRZB and DKK1 mRNA levels correlate with osteoarthritis and are regulated by osteoarthritis-associated factors. Arthritis Res Ther. 2013;15:R126.

57. Boyan BD, Hart DA, Enoka RM, Nicolella DP, Resnick E, Berkley K, et al.

Hormonal modulation of connective tissue homeostasis and sex differences in risk for osteoarthritis of the knee. Biol Sex Differ. 2013;4:3,6410-4-3.

58. Lang TF. The bone-muscle relationship in men and women. J Osteoporos. 2011:2011:702735.

59. Clark AL, Votta BJ, Kumar S, Liedtke W, Guilak F. Chondroprotective role of the osmotically sensitive ion channel transient receptor potential vanilloid 4 : age- and sex-dependent progression of osteoarthritis in Trpv4-deficient mice. Arthritis Rheum. 2010;62:2973-83.

60. Li ZC, Dai LY, Jiang LS, Qiu S. Difference in subchondral cancellous bone between postmenopausal women with hip osteoarthritis and osteoporotic fracture: implication for fatigue microdamage, bone microarchitecture, and biomechanical properties. Arthritis Rheum. 2012;64:3955-62.

Submit your next manuscript to BioMed Central and we will help you at every step:

- We accept pre-submission inquiries

- Our selector tool helps you to find the most relevant journal

- We provide round the clock customer support

- Convenient online submission

- Thorough peer review

- Inclusion in PubMed and all major indexing services

- Maximum visibility for your research

Submit your manuscript at www.biomedcentral.com/submit
Biomed Central 